\title{
I found a family through sociotherapy
}

\section{Mameritha Nyiramana}

I was born in the Southern Province of Rwanda. My parents were cattle keepers. We were ten children. We are now four because the other six died during the genocide. Before the genocide, I never experienced any violence. The first time I encountered violence was during the genocide, when I was nineteen years old. I was raped and I gave birth to a child of the Interahamwe. I have good memories of my life before the genocide, especially of meeting up with my friends. It hurts that I no longer see them, because the genocide separated us. I now live with my three children and a husband. The oldest child is seventeen years old, the second one is three years old, and the last one is one year old.

At the beginning of the genocide we were all at home. We saw houses being burned on the other side of our neighbourhood.

Suddenly I saw many aggressive men coming towards our home. They had machetes and sticks. I then heard my mother telling us, "Run away because they are coming to kill us." We fled separately, each searching for a place to hide. I decided to hide in the forest, expecting nobody to find me there. I spent three days alone in the forest. Then the Interahamwe found me and raped me. Most of them left as soon as they arrived, but four of them stayed with me. They tore my clothes to pieces and started to rape me one after another while the others watched. After that catastrophic experience I lost consciousness. When I awoke I was still in the same place. After regaining some strength, I got up and wandered aimlessly in the streets. Seeing me like this, the Interahamwe raped me again several times.
A few days after the rape I felt unwell and thought that it was because of hunger and the rape which had been so sadistically forced on me by so many men. At the time I knew nothing about pregnancy because the rape was the first time I had sexual intercourse. Not realising that I could be pregnant, I continued to think that the illness was related to the rape. Once I found out, I felt intensely downhearted. If I had had knowledge on how to abort, I would have done that. It was very difficult for me to accept that I was pregnant from the Interahamwe. I agonized and worried about how I could raise a child of a man I never loved. I was depressed.

At the same time, I was continually on the move, fleeing from the gunshots that kept going off all around us. People were dying everywhere, especially at roadblocks. I followed others who were fleeing but I was not afraid of being killed. There could not be more death than being raped by many unknown men. After a long time of being on the run, I found myself in the house of an old woman in Gisenyi. I had gone there searching for food. After the woman gave me something to eat, she allowed me to stay with her. When the war got worse she and I fled together to Congo.

It was in the refugee camp in Congo that I gave birth to my firstborn. I then developed malnutrition because of the dreadful living conditions. In 1995, helped by the UN Refugee Agency, I returned with my daughter to Rwanda. I went to live with my uncle's family in Bugesera. I reunited with my mother who had recently come back from the bush. My mother did not recognize me 
because I was half dead. I was hospitalized for a long time because of malnutrition. While I was at the hospital, my mother took care of me. This helped me to tell her that I had been raped and that I had given birth to a child of the Interahamwe. We continued to live in my uncle's place until my mother was given a house in a group of newly built houses for poor and vulnerable people. Fifteen years later, the uncle who had been supporting us passed away. Our living conditions started to deteriorate because neither I nor my mother was working. We also did not have anywhere to cultivate. Because of that, I started cohabiting with a man with whom I then had two children. Truly, I did not love him; I accepted him because he brought us food after my uncle's death.

I have long been depressed, hating my firstborn and suffering from persistent headaches. I always felt anxious and had difficulties sleeping. I suffered from back pains and sexually transmitted infections. I still do not know the identities of the men who raped me, which causes me much sorrow. Perhaps I could have found out something about the Interahamwe who hurt me through the Gacaca courts, but I did not actively participate in Gacaca because I felt I had nothing to say.

The first time that I did participate in Gacaca, it seemed as if my head was going to explode. This happened when men started explaining how they killed my little brother, who was five years old at the time. I felt particular anguish when the Interahamwe explained how they killed him, and said that my brother had begged them not to kill him because he promised that he would no longer be a Tutsi. As they continued to elaborate on this, I felt immeasurable grief in my heart. They also said that they threw my father and my big brother into the latrine and killed them by throwing stones at them. These killers' statements were addressed to my mother. After a while I felt my head get hot and I started losing my mind. While listening to this, I thought about what had happened to me, and was afraid that the rapists might repeat what they had done to me in the Gacaca court. I felt deep pain at hearing the killers describe the deaths of my family members. While they were talking I couldn't sit still, I did not know what to do or where to look. I left Gacaca before the end of the session and went back home. I felt intense sadness, anger and grief. I was confused, my head felt very painful, and I felt nauseous but was not able to vomit. At that point I decided not to attend any other Gacaca sessions because what I heard while there was too troubling.

Even though attending Gacaca was difficult for me, hearing the perpetrators tell the truth about the way my siblings were killed and where they had been thrown helped me bury them in dignity. That relieved my heart and I felt that I should forgive them. If I didn't, I would be the one continuing to suffer. So I forgave them and as a result was able to talk to them. But the confidence I have in them is no longer complete. Our relationship cannot be like it was before the genocide. Gacaca brought Rwandans together and it facilitated communication between Hutus and Tutsis. It has helped the genocidaires ask for pardon. Survivors felt released after hearing more about the death of their loved ones and where to find their remains. As a result, some survivors, like me, forgave the killers of their relatives. For me, justice has been done because the genocidaires were imprisoned. But still, there are those who are in prison but refuse to accept the sin committed against other families. For me, what remains to be done by Gacaca is to pay back our 
property that was looted. The courts must review all cases of looted property, identify in which cases looting was carried out by people who are so poor that they are unable to refund the damage. In those cases, the courts might be able to take responsibility for the necessary refunds.

Due to all these sorrows, I often experienced severe psychological problems, especially during the commemoration period. One of the symptoms is feeling like something is walking inside my head. I avoid going to church while genocide commemoration ceremonies are held there; instead I hide in my bed. Last April (2012), however, I did not suffer from ihahamuka. I only experienced headaches. Because of various methods of training and counselling, I am slowly managing to cope with my suffering a little bit better. In terms of support, AVEGA helped me treat the rape-related sexually transmitted infections, as well as providing trauma counselling. Since the AVEGA headquarters are located in Kigali, which is relatively far from where I live, the AVEGA counsellor referred me to an Ibuka counsellor at the Nyamata health centre, where I could continue benefitting from individual trauma counselling. This kind of support reduced my headaches and helped me forgive the killers. After forgiving them, it felt as though my heart was released.

While I was following the counselling sessions, the counsellor connected me with the Kanyarwanda Association, which is now sponsoring my firstborn. I was then invited to take part in a forum of women who have children born out of rape. After participating for three days, I was able to disclose to my daughter how she was conceived. This helped stop my daughter's relentless questioning about who her father is. It was good to tell my daughter the truth, because before I was always transferring my anger and sadness onto her. I saw her as the source of my suffering. As a result of being trained by Kanyarwanda, I started to take care of her. This had a positive impact on her. She improved somewhat in her studies. Later, when Kanyarwanda provided some money for income generating activities to its members, we formed a group of women who visit each other and bring our children born out of rape together. As a group, we visit two members per month. We then eat together, chat and pray.

When I was still benefitting from the support given by FARG, I was able to buy mutual health insurance for my children. However, I am no longer on the list of beneficiaries for this support.

Even though I benefitted from trauma counselling, I remained anxious. As such, I continued to consult trauma counselling services, because I wanted to feel secure like others. Once I went to the African Evangelical Enterprise (AEE), which resulted in an invitation to follow trauma counselling and reconciliation training. During that training I met a lot of people who, like me, had many problems. One of these, a woman, later invited me to join sociotherapy. There, I met women who had also been raped during the genocide. It was the first time for me to sit with old women as a group and talk about these secret issues.

When I decided to follow all sociotherapy sessions, it was in the expectation of continuing to talk to other women, to cry and to smile. What made me happy was that we were the same and all had the same bad experiences. So when you start talking in the group everyone listens. Today I am happy because I really found what I had hoped for. Because we knew each other, I did not feel any of the usual fear. Meeting other women helped me to be open and talk honestly. I appreciated the exchanges and discussions 
we had together. After speaking out my sadness I felt my problems decreasing. I had never been able to like my firstborn before. After joining sociotherapy I accepted her and loved her. I treat her better now, and I try to help. Before I felt shame because of the rapes, but since participating in sociotherapy I accept myself and I no longer feel ashamed. I was able to forgive the killers of my siblings and father. Some of the physical problems, such as the nausea and headaches, disappeared. I now live in peace with my neighbours and my relationships with other people have also changed for the better. Before, when I had a problem with someone, I used to keep it inside my heart because I was rancorous. The lessons I received from sociotherapy ameliorated this and thus helped my relationships with others.

I learnt that to forgive and ask for pardon are two deeply significant things. When you seek pardon, you feel relieved in your heart. And at the same time, when a person who is asked to forgive offers that pardon, he/she also feels released and the relationship becomes better.

Because my behaviour changed while participating in sociotherapy, my husband's behaviour also changed. Before, we communicated badly with each other and sometimes fought. He squandered all his salary away at the local bar. What saddened me most was when he used to say that he is only working for my daughter born out of rape. Sociotherapy helped me get closer to him and to talk to him without using bad words. Learning more and more from sociotherapy, I was able to be more humble with him and I started to respect him. Now, when he has money, he gives me part of it. He no longer spends his nights drinking and he does not insult me the way he used to. My husband asked me for forgiveness, I forgave him, and our relationship was restored thanks to good communication. We now plan everything that we will do at home together. I now have serenity in my house.

I have become free in my heart. The sociotherapy group is like my family. The older women take care of me. Looking at the future, I expect to do some small business whenever I receive a small amount of money. I hope that one day I can sell offspring from the goat which I received from the sociotherapy programme, and then have enough to further invest in that small business. I am worried about finding my own house; it is my only burden now.

I shared my story here in order to inform other women who are like me that healing is possible. Wherever you are, do not feel guilty. I advise all women to get together, sit somewhere in an intimate place and share your sadness. After being listened to and sharing advice, every woman will feel strength and hope for the future. 